\title{
The Implementation of 'Market Day' Activities to Improve Children Entrepreneurship at Telkom Preschool Ternate
}

\author{
Farida Samad ${ }^{* 1}$, Rosita Wondal ${ }^{2}$, Nurhamsa Mahmud ${ }^{3}$, Haryati $^{4}$, Natalia Purba ${ }^{5}$ \\ ${ }^{1,2,3}$ Universitas Khairun Ternate \\ ${ }^{4}$ Institut Pendidikan Agama Negeri Ternate \\ ${ }^{5}$ Universitas HKBP Nommensen Pematangsiantar \\ *Corresponding Author. Email: faridasamad81@gmail.com
}

\begin{abstract}
This study aims to describe the implementation of 'market day' activities to improve children entrepreneurship learning at Telkom Preschool Ternate. The research method used is descriptive qualitative. The subjects of this research were students and teachers of group B Telkom Preschool in academic year 2019/2020. Data collection used direct observation, in-depth interviews and documentary methods. The data were analyzed qualitatively with such stages of reduction, presentation of data, verification and conclusion. The result showed that the implementation of the 'market day' or school market activities in Telkom preschool Ternate has integrated with entrepreneurial values based on Telkom preschool curriculum. The students were able to get direct experience about entrepreneurship value. All students in A1, A2, A3, B1, B2, B3 groups felt enthusiastic and motivated when buying and selling activities. The learning activities from the beginning to the end were done in accordance with the principles of learning for early childhood and directed towards the achievement of learning objectives. Thus, it will improve children's cognitive abilities and entrepreneurial skills from an early age.
\end{abstract} Article History

Received: $25-03-2021$

Revised: 31-05-2021

Accepted: 29-07-2021

Published: 07-09-2021

Key Words:

Market Day,

Entrepreneurship,

Early Childhood

Education.

How to Cite: Samad, F., Wondal, R., Mahmud, N., Haryati, H., \& Purba, N. (2021). The Implementation of 'Market Day' Activities to Improve Children Entrepreneurship at Telkom Preschool Ternate. Jurnal Kependidikan: Jurnal Hasil Penelitian dan Kajian Kepustakaan di Bidang Pendidikan, Pengajaran dan Pembelajaran, 7(3), 511-519. doi:https://doi.org/10.33394/jk.v7i3.3597

\section{Introduction}

Early childhood education is defined as the level of education before primary education which is an approach to development that is intended for children from birth to six years old. During this stage, children are highly influenced by the environment and the people that surround themy way. The series of learning processes in early childhood is designed in a fun and child. Children do not feel that they are learning but playing. Through the context of play, the teacher instills a number of learning content so that children can grow and develop as optimally as possible. Raposo \& do Paço (2011) state that children do not only receive academic educational services, but educational institutions also teach them to develop an entrepreneurial spirit, with various specific goals. Implementing children enterpreneurship value in early childhood will form individuals who have several skills, including: 1) managerial skills, 2) conceptual skills, 3) human skills, 4) decision making skills and 5) time managerial skills (Suzanti \& Maesaroh, 2018). Singapore, which has 4\% entrepreneurs of the total population, while Indonesia is only $0.18 \%$ of the total population of 225 million, this is not because the majority of Singaporeans are Chinese and Indonesia is a Javanese majority. But this happens because of the imbalance in entrepreneurship education so that entrepreneurship education is an important need in Singapore, in contrast to Indonesia, which is still not maximally implementing entrepreneurial character and behavior (Handayati et al., 
2020). Unemployment and poverty are still problems in Indonesia. Unemployment and poverty occur because the ratio between the number of job opportunities offered is not proportional to the number of graduates or the supply of new workers at all levels of education. The phenomenon of the current state of the nation has shown that foreign workers are starting to enter our country, Indonesia. This is what makes our nation must be prepared to develop various efforts to help the family economy and generally the nation's economy (Nagib \& Ngadi, 2008) (Wahid, 2017).

One of the activities that can be used to develop an entrepreneurial spirit is market day activities. Previous studies on implementing entrepreneurship value for early childhood were conducted by (El Khuluqo, 2017), (Rina et al., 2019), (Suharyoto, 2017), (Prasetyaningsih, 2016). Market day is an activity that can be carried out independently by children with the help of class teachers in producing items individually or classically / in groups according to student interests or learning themes discussed in class. The product will be marketed on a certain day.

Telkom Preschool Ternate is one of kindergartens in Ternate that includes entrepreneurship in their school materials. It is a routine program conducted every year. To foster the entrepreneurial spirit through 'market day' or the school market, students will be taught on how to make simple products that can be sold. With the income they get from the sale, they will donate money to the surrounding community. Teaching entrepreneurship as a part of the school curriculum focuses on developing real world skill that will help student's lead exceptional lives in rapidly changing world. Moreover, the value teaches children essential life skills such as problem solving, empathy, how to collaborate and work with team, how to use curiosity and creativity as well as learning to accept failure as a part of the growth process. The earlier they are introduced to the world of business, the bigger the impact they can make. It is expected that 'market day' activities can improve children entrepreneurship learning at Telkom Preschool Ternate.

\section{Research Method}

This research uses qualitative approach with a descriptive research design. The subjects were teachers and a 5-6 year students who had learned in the activities' Market Day 'in February-March of academic year 2019/2020. This research used an observation sheet instrument in the form of a checklist. A checklist or checklist is an observation guide which contains a list of all aspects to be observed related to the 'Market Day' activity. Meanwhile, the method of interviewing research subjects, including the principal and the class teacher with the aim of knowing how implementation activities was conducted in shaping the spirit of early childhood entrepreneurship at Telkom Preschool Ternate as well as supporting and inhibiting factors for the implementation of its activities. For this reason, tools were used in the form of interview guidelines so that they were directed and were in accordance with the specified focus. The documentation were the 2013 PAUD curriculum, the annual program, weekly activity plan (RPPM) and daily activity plan (RPPH) which were commonly used by teachers and group B student assessments. The data analysis technique used was qualitative data analysis with the following steps (Huberman \& Miles, 2012) such as data reduction, presentation of data, verification and conclusion. In carrying out this step, it uses triangulation and member check. 


\section{Finding and Discussion \\ Market Day Activities}

Market day is one of the entrepreneurial activities in which students are taught on how to market products in their small scope such as friends, teachers or other. This activity is usually like a bazaar or market held at school. Based on the results, the teacher and students determine the basic problem that will be used as a project, namely how to make a simple market to meet the needs of the school community. At this stage the teacher divides students into groups to create a plan. Teachers and headmaster discuss together to determine the day and date of the 'market day' activity. Then, the teacher helps the child make works for the activity. They also involve parents in it. The steps include: giving announcement to parents about 'market day' activities will be conducted, preparing the children's work that has been made and discussing with parents what product which will be sold on 'market day' activities. This step is very important to determine the success of the project implementation. Teachers schedule the implementation of market day held at school. It is needed to ensure that project stages are carried out well and on time. By making a time schedule, all student activities starting from preparation, implementation to project evaluation are recorded and scheduled as expected.

The activity was officially opened by the headmaster. Various sales stands are lined up neatly in the yard of the school which is filled by students with their teachers and parents. They arrange items to be sold to buyers to make them look attractive. Through this market day event, it can be a learning tool for students in fostering an entrepreneurial spirit from an early age because in this activity they can see the interactions between sellers and buyers. In this activity, the results of the production or work of the students' parents and students are displayed for sale and consumption by visitors. The event, which was packaged like a market, made the Telkom Kindergarten children. They look enthusiastic about the products being sold at their respective stands. Moreover, all teachers are very satisfied because all students look happy and excited to be able to play an active and interactive role with friends and parents who come to visit the stand proudly offering and serving the buyers of their selling items. Parents look happy watching the development process of their children at school. This is also an event for the school's extended family to gather in friendly, relaxed and harmonious manner. There is also learning about economics, cognitive and there is also a religious side. In addition, children can also learn about how to identify their merchandise and socialize with other people. There are not significant obstacles found during the activity since it began in 2016. Every year the activities are even more interesting.

The assessment so far is still in the form of observations regarding the extent to which the participation or performance of teachers in preparing, arranging and their creative attitudes in guiding, organizing and directing their students to be more creative and active so that this activity looks 'alive' and interesting. In the criteria for child development, the teacher provides direction and motivation to the child to be able to carry out buying and selling transactions so that this is made a separate note for the teacher in the assessment, even though this is done not formally. Moreover monitoring is carried out by the principal by means of him going down directly to see every stand that sells and also monitoring the homeroom teacher and students by providing motivation because there are still some children who are shy in selling activities or interacting with other people.

Based on the results of observations of curriculum documents and its process as follows:

a) The 'market day' activity implemented by Telkom preschool Ternate, which is one of the school's favorite activities that students really like, is the culmination of the 
theme of the last theme in semester one, namely 'entrepreneurship', it usually held at the end of semester one or the beginning of semester two . The objectives of this activity include:

- Learners

To instill an entrepreneurial spirit from an early age in accordance with creativity and innovation can improve six aspects of early childhood development in an active and interactive.

- Parents

Parents can use this activity to show their support for the educational process and the development of children in school.

- Schools and teachers

Both can take advantage of the 'market day' vehicle to strengthen the solidarity of the school community.

Regarding the planning for this activity, it has been arranged according to the Telkom school curriculum in collaboration with the parents of the students and the activities are carried out in the school yard. Preparation is carried out by the teacher together with all students in their respective classes by making creative arts and crafts from used materials into interesting and useful materials and of course they can be sold in market day activities during the first semester of learning. In addition, the creative work of students and teachers in the market day activity was also enlivened by selling food processed by parents that were suitable and attractive for students at school. In order to enliven this activity,

b) The observation results on 'market day' activities create a future creative generation with them 'instilling an entrepreneurial spirit from an early age' which was held on monday, February 1, 2020 at 08.00-11.00 in Telkom school yard; (1) even though it seems that they are just chattering about each other, there is good interaction and communication between the children. There are children who act as sellers and buyers with all their needs and money in hand or the child has a number of items in the form of work to be sold, (2) Children learn how to communicate according to the role played according to the direction of the class teacher, both when buying and selling, (3) it makes children understand the function of money in relation to the amount of money they will spend, of course, is abstract whether the money they spend when buying large amounts or not. However, in this case the child will know that the work they buy is valuable because he will be redeemed with the amount of money provided, (4) it will motivate students to train entrepreneurial skills from an early age. By introducing this trading activity directly, teachers and parents have introduced the spirit of entrepreneurship to children related to how children try to sell their work to their friends. It will improve children's cognitive abilities, to train children's creative abilities and entrepreneurial spirit, (4) it will motivate students to train entrepreneurial skills from an early age. By introducing this trading activity directly, teachers and parents have introduced the spirit of entrepreneurship to children related to how children try to sell their work to their friends. This will improve children's cognitive abilities and of course also train children's creative abilities and entrepreneurial spirit. However, in this case the child will know that the work they buy is valuable because they will be redeemed by the amount of money provided, (4) it will motivate students to train entrepreneurial skills from an early age. By introducing this trading activity directly, teachers and parents 
have introduced the spirit of entrepreneurship to children related to how children try to sell their work to their friends. This will improve children's cognitive abilities and of course also train children's creativity and entrepreneurial skills. The following are some of 'market day' activities:

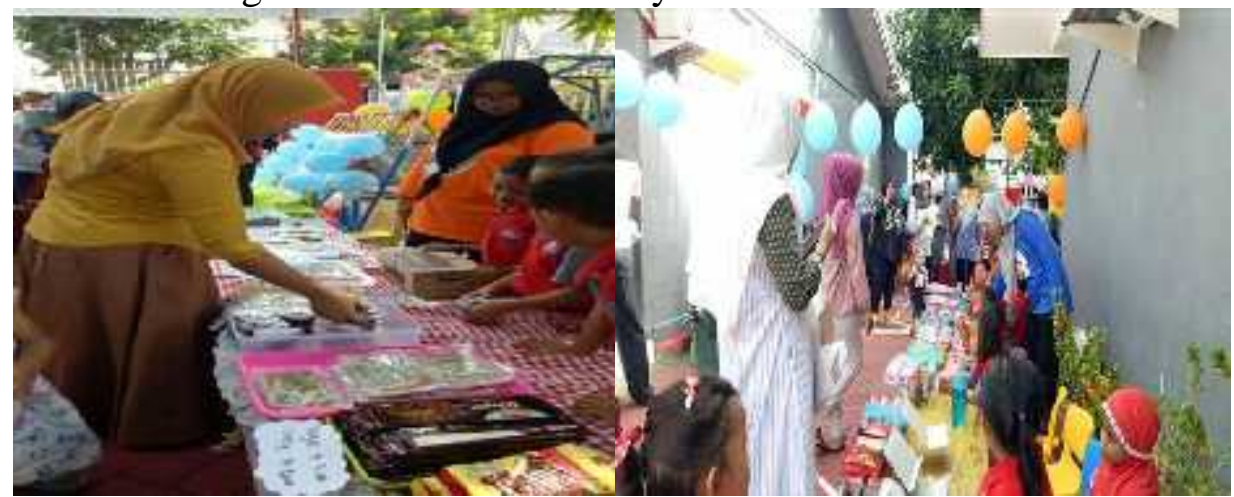

Figure 1. Selling and Buying Activities Carried Out by Students and Parents
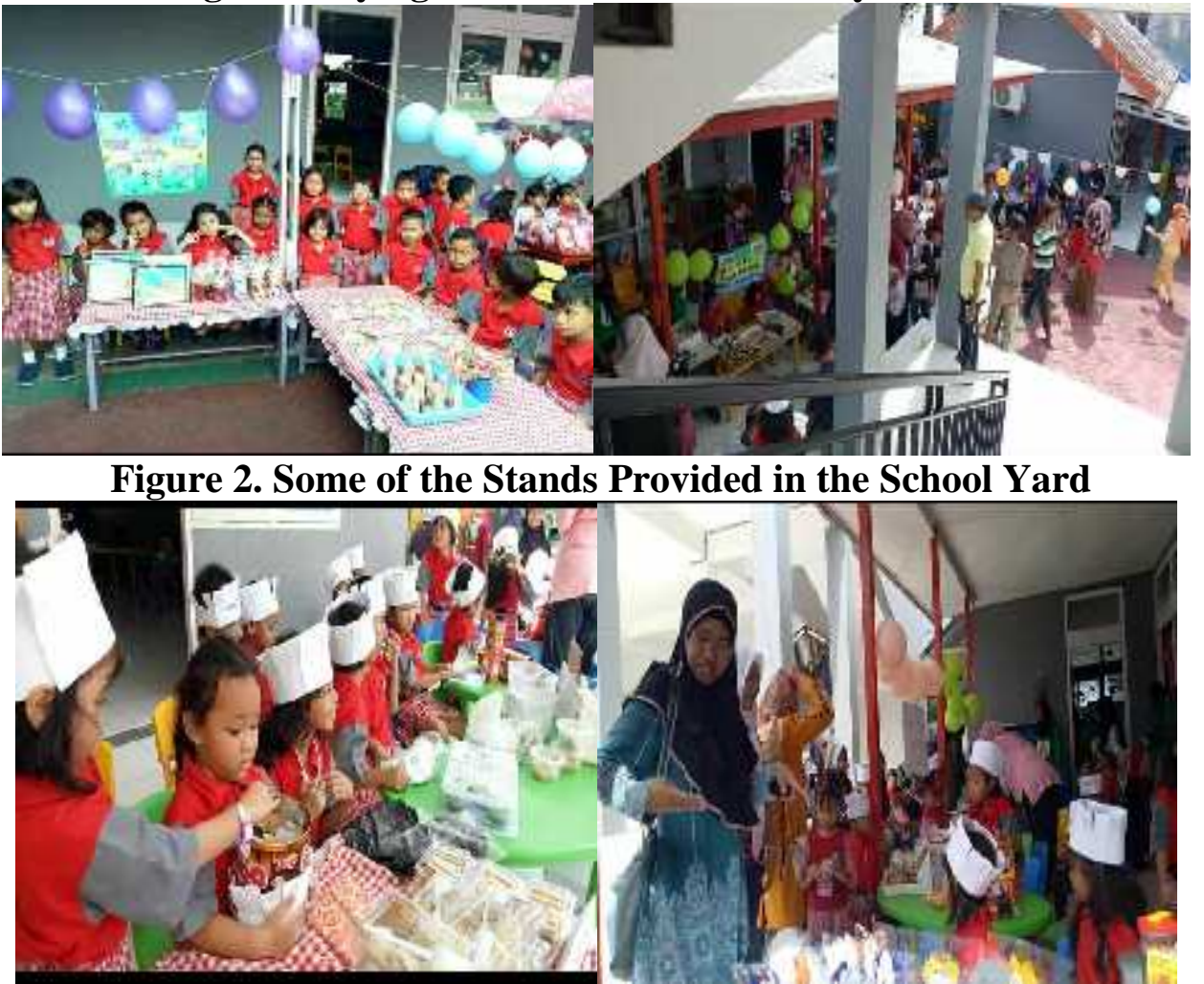

Figure 3. The Joy of Students and Parents During 'Market Day' Activities

\section{Discussion}

Based on the results of the research data that have been stated, the researcher will describe the discussion of the research results as follows:

Data from interviews, observation data from researchers and review data from documentation show that the implementation of market day or school market activities at Telkom Preschool Ternate is a routine activity held to integrate entrepreneurial values from an early age or learning activities that are 'entrepreneurial'. This activity is implemented once every semester and at the end of the theme as learning by introducing trading practices from an early age which involves all students in the process of production, distribution, and 
consumption. Production activities in the market day are carried out by the teacher giving responsibility to students based on study groups A and B which in turn make works or products, creativity in arts and crafts from used materials and are interesting and useful and can be sold and of course have selling points for all school academics during market day activities during learning in the first semester at Telkom Preschool. Market day activities can be carried out independently or classically according to student interests and the products to be produced.

This activity takes the form of a bazzar or market organized by schools. The works to be marketed are any products that will be sold based on market themes and interests, where students act as sellers, which are sold, namely food, drinks, stationery, accessories and others. In addition, the teachers and parents are also involved in preparing merchandise. Generally, the buyers are students, teachers, and parents. Each class generally has its own merchandise booth. Sometimes each class presents its own unique theme and merchandise. In addition, some of the students' work or products can also be displayed and tried to be sold to friends or teachers who were present at that time. A cheerful atmosphere created in the school market activity so that all students feel happy. Some students are tasked with selling merchandise, some will serve purchases and some will receive payments. In fact there are most students who are also provided with more pocket money that day than usual. With the aim that pocket money can be used to participate in shopping for food, drinks, souvenirs or toys sold on the market day. The money from sales is usually used as a fund to pay for class activities; it can also be partially saved in the savings of the children at school.

With this market day activity, children are expected to be educated from an early age on how to sell well. In this case they will be familiar with the concept of honesty, for example in the scales, measurements, which items are good and which are damaged. The purpose of holding a 'market day' is to foster an entrepreneurial spirit, understand the world of business, train creativity and innovation in students. In addition, this 'market day' activity can also foster self-confidence in children, increase children's communication skills and train children's business intelligence. Parents can take advantage of market day activities to show their support for the educational process of their children, while teachers and schools can take advantage of market day vehicles to strengthen school community solidity if the market day is running optimally.

According to Nurhayati (2018), Anjarwani (2016), (Axelsson et al., 2015) this activity not only teaches about transaction procedures for students but also entrepreneurial values that can be applied, including:

a) Confidence: Attitudes and behavior to be able to understand and believe in all of their potential so that they can be used in the face adjustment with the environment.

b) Creative: Thinking and doing something to create new things or new ways that are different from something that has been there before.

c) Hard work: a job that is done in earnest. The work is carried out tirelessly, or stops before reaching the desired target

d) Honest: an attitude that is upright, stating that it is not true that you are lying or saying things that contradict what happened (facts).

e) Discipline: a sense of obedience and obedience to the stated values and responsibility. In other words, discipline is obeying the rules or subject to supervision and control.

f) Cooperation: work carried out by two or more people in order to achieve goals or targets that were previously planned and also mutually agreed upon.

g) Curiosity: Attitudes and actions that always seek to know deeply and broadly from what is learned, seen, and heard. 
h) Communicative: Actions that show enjoyment of talking, socializing, and cooperating with others

Thus entrepreneurship leads to mental changes. The following are the benefits and objectives obtained from market day activities by several researchers: (Prasetyaningsih, 2016), 'market day' aims to foster an entrepreneurial spirit, understand the world of business, train creativity and innovation in students, foster self-confidence in children, increase children's communication skills and train children's business intelligence. (Diana et al., 2017) reveals that the cultivation of entrepreneurial values in early childhood consists of 6 main things, namely: independence, creativity, risk taking, leadership, action orientation, and hard work. Handayati et al., (2020) (Hassi, 2016) state that market day program also has an impact on economic conditions in the family, with the training in the market day program, the economic income level of the family is expected to increase. Therefore, entrepreneurship education training is important for early childhood through market day activities.

Moreover, Sjamsir et al., (2019) also revealed that entrepreneurship education can also train children to innovate as children can do creativity in food packaging. It includes activities that can develop soft skills such as entrepreneurial, creative, courageous, responsible, and so on. The application and development of skills carried out from an early age will provide a strong foundation for children's entrepreneurial abilities. (Raposo \& do Paço, 2011) state that market day includes activities that can develop soft skills such as entrepreneurial, creative, courageous, responsible, and so on. The application and development of skills carried out from an early age will provide a strong foundation for children's entrepreneurial abilities. By integrating entrepreneurship education in the learning process both planning, implementing and evaluating learning in every aspect taught in kindergarten, children will have entrepreneurial values until they grow up. So that after graduating from school, they will no longer be job seekers but will open jobs. Entrepreneurship is not only the world of adults, but also can be part of the world of children. The difference is that entrepreneurship in children cannot be carried out alone, but requires guidance and support from adults, parents and teachers.

Meanwhile, do Paço \& Palinhas (2011) explain that children know the world of entrepreneurship from an early age, will get great benefits for the future provision. At an early age, children who learn to foster entrepreneurial learning will grow into creative personalities. Trained creativity from an early age, including through various entrepreneurial activities, is the main capital for children's productivity and independence when they grow up. An entrepreneurial spirit (entrepreneurship) must be instilled by parents and schools when their children are at an early age. Given that entrepreneurship is more about driving mental change. So there is no need to argue whether the entrepreneurial ability is due to talent or the result of the educational process (Derksen, 2003). A person who has an entrepreneurial spirit has a productive, creative, innovative, imaginative, professional, risk-taking personality, dares to act fast, hardworking, disciplined, resilient, persistent, diligent, energetic, hardworking, profit-oriented, creates excellence, is ready to accept risks and loss, act economically, be optimistic, believe self, don't give up easily. These traits can be cultivated from an early age.

Learning entrepreneurship in children requires gradual practice. It can be started from child's daily activities. For example, tidying up toys after playing, regularly brushing your teeth before going to bed and making the bed. This is a disciplined, responsible exercise and the beginning of teaching about ownership. The next exercise, teaches children to be able to manage money well. The exercises that need to be taught are not only how to spend, but also how to save, give alms and earn money. 


\section{Conclusion}

The implementation of the 'market day' activity or school market in Telkom preschool Ternate has integrated entrepreneurial values into the theme of learning according to the Telkom school curriculum that students are able to get direct experience about entrepreneurship. All students in each groups A1, A2, A3 and groups B1, B2, B3 felt enthusiastic and motivated when the buying and selling activities were carried out. By introducing trading activity, teachers and parents directly introduce the spirit of entrepreneurship to children related to how children try to sell their work to their friends.

\section{Suggestion}

There must be coordination of school before the market day activities implemented by having a meeting with parents so that it becomes the most beautiful experience for children in instilling the entrepreneurial spirit for the future. Instilling an entrepreneurial spirit in children can also be done from the smallest and simplest things that are close to children's lives. By relying on children hobbies, creativity and imagination and also support and guidance from parents, children can be more focused in creating something that can be useful for others and profitable for themselves.

\section{References}

Anjarwani, R. (2016). Membangun Jiwa Kewirausahaan Pada Anak Usia Dini dengan Permainan Tradisional Pasaran. Seminar Nasional Pgsd 2016, 5-10.

Axelsson, K., Hägglund, S., \& Sandberg, A. (2015). Entrepreneurial Learning in Education Preschool as a Take-Off for the Entrepreneurial Self. Journal of Education and Training, 2(2), 40. https://doi.org/10.5296/jet.v2i2.7350

Derksen, V. L. (2003). Hypermedia construction in an elementary school: A case study. ProQuest Dissertations and 172. http://search.proquest.com/docview/305349685?accountid=7098\%5Cnhttp://tuprimo.hosted.exlibrisgroup.com/openurl/01TTU/01TTU_SERVICES ?genre=dissertat ions $+\% 26+$ theses \&atitle $=\&$ author $=$ Derksen $\% 2 \mathrm{C}+$ Vickie + Lorraine $\&$ volume $=\&$ issue $=$ \&spage $=\&$ date $=2003 \&$ rft.btitle $=\&$ rft.

Diana, D., Windiarti, R., \& Astuti, H. P. (2017). Developing Enterpreneurship Activity Based on Local Culture in Early Childhood. 118, 502-507. https://doi.org/10.2991/icset17.2017.83

do Paço, A., \& Palinhas, M. J. (2011). Teaching entrepreneurship to children: A case study. Journal of Vocational Education and Training, 63(4), 593-608. https://doi.org/10.1080/13636820.2011.609317

El Khuluqo, I. (2017). Early Childhood Entrepreneurship Education: a Brief Description of an Ideal Entrepreneurship Learning for Middle Childhood. IMC 2016 Proceedings, $1(1), 818-827$.

Handayati, P., Wulandari, D., Soetjipto, B. E., Wibowo, A., \& Narmaditya, B. S. (2020). Does entrepreneurship education promote vocational students' entrepreneurial mindset? Heliyon, 6(11), e05426. https://doi.org/10.1016/j.heliyon.2020.e05426

Hassi, A. (2016). Effectiveness of early entrepreneurship education at the primary school level: Evidence from a field research in Morocco. Citizenship, Social and Economics Education, 15(2), 83-103. https://doi.org/10.1177/2047173416650448

Huberman, A., \& Miles, M. (2012). Understanding and Validity in Qualitative Research. In The Qualitative Researcher's Companion. https://doi.org/10.4135/9781412986274.n2 
Nagib, L., \& Ngadi. (2008). Challenges of Unemployment in Indonesia: Trends, Issues and Policies. Jurnal Kependudukan Indonesia, 3(2), 1-28. http://ejurnal.kependudukan.lipi.go.id/index.php/jki/article/view/167

Nurhayati, E. C. (2018). Pengaruh Market Day (Bazar) Terhadap Membangun Jiwa Wirausaha Mahasiswa Unsiq Jawa Tengah Di Wonosobo. Paramurobi: Jurnal Pendidikan Agama Islam, 1(2), 1-16. https://doi.org/10.32699/paramurobi.v1i2.522

Prasetyaningsih, A. (2016). Membentuk Jiwa Kewirausahaan pada Anak Usia Dini melalui Kegiatan "Market Day.” SELING: Jurnal Program Studi ..., 2, 88-102.

Raposo, M., \& do Paço, A. (2011). Entrepreneurship education: relationship between education and entrepreneurial activity. Psicothema, 23(3), 453-457. http://www.ncbi.nlm.nih.gov/pubmed/21774900

Rina, L., Murtini, W., \& Indriayu, M. (2019). Entrepreneurship Education: Is It Important for Middle School Students? Dinamika Pendidikan, 14(1), 47-59. https://doi.org/10.15294/dp.v14i1.15126

Sjamsir, H., Jafar, F. S., \& Alfiah, A. (2019). The Cultivation of Entrepreneurship Values in Children Aged 5-6 Years at TK Khalifah Samarinda. 224(Esic 2018), 12-15. https://doi.org/10.2991/esic-18.2019.4

Suharyoto, L. S. (2017). Menanamkan Nilai Kewirausahaan Melalui Kegiatan Market Day. Golden Age: Jurnal Pendidikan Anak Usia Dini, 1(1), 15-17. https://doi.org/10.29313/ga.v1i1.2861

Suzanti, L., \& Maesaroh, S. (2018). Entrepreneurship Learning for Early Childhood. January 2017, 403-410. https://doi.org/10.5220/0006887004030410

Wahid, S. (2017). Theory and Practice of Entrepreneurship Education in Higher Education: Case Study PLS FIP UNP. Seminar Nasional Pendidikan Nonformal FKIP Universitas Bengkulu, 1(July 2017), 184-198. 